\author{
DOMINIKA KUŹNICKA-BŁASZKOWSKA \\ ORCID: 0000-0001-8804-569X \\ Uniwersytet Wrocławski
}

\title{
ROZPROSZONY SYSTEM ORGANÓW STOJĄCYCH NA STRAŻY NIEZALEŻNOŚCI I NIEZAWISŁOŚCI SĘDZIÓW W IRLANDII
}

\begin{abstract}
Abstrakt: W rankingu przeprowadzonym przez Komisję Europejską system władzy sądowniczej w Irlandii został zakwalifikowany jako drugi w Europie, ze względu na wysoki stopień niezależności sądów od pozostałych organów. Jednocześnie system ten, inaczej niż w wielu innych państwach Europy, ma charakter silnie rozproszony. Ostatnie lata to czas reformy organizacji sądownictwa, a wprowadzona w lipcu 2019 roku ustawa The Judicial Council Act miała rozwiązać większość palących problemów. Pomimo wyposażenia nowo powstałej Rady Sądowniczej w wiele kompetencji wydaje się, że bez gruntownej zmiany całego systemu i stworzenia organu, który byłby odpowiedzialny za wykonywanie przynajmniej większości zadań związanych z administrowaniem sądownictwa, sytuacja sędziów w Irlandii się nie poprawi.
\end{abstract}

Słowa kluczowe: Irlandia, reforma sądownictwa, Rada Sądownicza

W rankingu przeprowadzonym przez Komisję Europejską system władzy sądowniczej w Irlandii został zakwalifikowany jako drugi w Europie, ze względu na wysoki stopień niezależności sądów od pozostałych organów ${ }^{1}$. Jednocześnie jest on (w 2019 roku) w trakcie największej od lat reformy ${ }^{2}$, dopiero bowiem w lipcu 2019 roku Oireachtas przyjęły ustawę o Radzie Sądowniczej ${ }^{3}$. Wiele nieformalnych organów zastąpił jeden, który skupi w swoich rękach najważniejsze dla organizacji wymiaru sprawiedliwości funkcje: szkolenie przyszłych i obecnych sędziów, prowadzenie i orzekanie w sprawach dyscyplinarnych sędziów, wybór sędziów i ich reprezentację w stosunkach z innymi organami państwa oraz ogólne zarządzanie administracją sądową.

1 L. Cahillane, Ireland's System for Disciplining and Removing Judges, 38 Dublin U. L.J. 55, 2015, s. 55.

2 Transformation Programme Overview, http://www.justice.ie/en/JELR/Pages/WP15000153 (dostęp: 28.09.2019).

3 The Judicial Council Act 2019. 
W doktrynie wskazuje się, że rzeczywistą siłę i autorytet sędziów i wymiaru sprawiedliwości kształtują następujące elementy: charakter i niezależność samych sędziów, system prawny, w ramach którego orzekają, oraz system polityczny ukształtowany w państwie ${ }^{4}$. W Irlandii, gdzie sądy odgrywają ogromną rolę w procesie interpretacji, a w wielu przypadkach w procesie stanowienia prawa, zapewnienie odpowiednich gwarancji niezależności i niezawisłości sędziów jest niezwykle istotne.

Pożądanym stanem jest skupienie w rękach jednego organu konstytucyjnego wskazanych zadań. W przypadku Irlandii po wieloletnim rozproszeniu ostatecznie przyjęto regulację, która ma zwiększyć niezależności i niezawisłości organu quasi-sądowniczego, chociaż wciąż niektóre tradycyjne kompetencje pozostały poza zakresem zadań Rady Sądowniczej

\section{GENEZA I POZYCJA USTROJOWA}

Irlandzki system prawny był kształtowany przez prawo Wielkiej Brytanii, które nieco zmienione zostało wdrożone jako common law Irlandii. Aż do traktatu w 1921 roku Irlandia była zarządzana w sposób gwarantujący realizację interesów angielskiej korony jako jej państwo wasalne, a po akcie unii z 1800 roku jako integralna część Zjednoczonego Królestwa ${ }^{5}$.

Początkowy etap rozwoju administracji sądowej trwał od odzyskania przez Irlandię niepodległości w 1922 roku do połowy lat dziewięćdziesiątych. Negocjacje podjęte w 1922 roku, które doprowadziły ostatecznie do rozłamu między Irlandią i Wielką Brytanią, wyznaczyły ramy reform prawnych przeprowadzanych w Irlandii niemal do końca XX wieku6 ${ }^{6}$ Jednym z osiągnięć 1922 roku jest z pewnością uchwalenie w Irlandii konstytucji, która obowiązywała do 1937 roku.

Konstytucja zarówno z 1922, jak i 1937 roku wymagała od sędziów pełnej niezależności, niestety żadna z nich nie określała, od kogo i od czego sędziowie powinni być niezależni. Wydaje się jednak oczywiste, że niezależność ta obejmuje nie tylko niezależność od stron postępowania prowadzonego przez sędziego, ale rzeczywistym celem art. 69 konstytucji z 1922 roku oraz art. 35 ust. 2 konstytucji z 1937 roku jest zapewnienie niezależności od organów władzy wykonawczej i ustawodawczej w kraju.

Do 1995 roku sędziowie byli mianowani w wyniku wyłącznie politycznej decyzji prezydenta i rządu na mocy art. 35 ust 1 konstytucji z 1937 roku. Gdy w 1994 roku Taoiseach mianował prezesa Sądu Najwyższego w wyjątkowo niepokojących

${ }^{4}$ C. Guarmieri, P. Pederzoli, The Power of Judges, Oxford 2002, s. 4.

5 T.F. O'Higgins, The Irish Legal System, 31 Irish Jurist (N.S.) 1, s. 1.

6 D. O'Donnell, Some Reflections on the Independence of the Judiciary in Ireland in 21st Century Europe, 19 Trinity C.L. Rev. 5, 2016, s. 6. 
okolicznościach, wywołało to protesty społeczne, a w konsekwencji upadek ówczesnego rządu koalicyjnego ${ }^{7}$. W efekcie tych wydarzeń parlament uchwalił ustawę Courts and Court Officers Act i powołano Radę Doradczą do spraw Nominacji Sędziowskich. Wprowadzenie nowej instytucji oraz zmiany w procedurze nominacji sędziów nie były poddane debacie publicznej, a również sami sędziowie nie mieli w tym zakresie możliwości wydania opinii ${ }^{8}$.

Do 2000 roku sędziowie nie mieli stałego przedstawiciela, który reprezentowałby ich interesy w kontaktach z pozostałymi organami władzy publicznej. Komitet do spraw etyki sędziowskiej w 2000 roku w swoim raporcie postulował powołanie rady sądowniczej ${ }^{9}$. Dnia 18 listopada 2011 roku sędziowie zawiązali Tymczasową Radę Sądową, której celem jest podnoszenie standardów etycznych i orzeczniczych, działalność na rzecz edukacji sędziów, a także reprezentowanie interesów sędziów i wymiaru sprawiedliwości w procesie legislacyjnym poprzez wydawanie opinii, zaleceń i włączania się w prace ustawodawcze, jeśli jest to możliwe ${ }^{10}$.

Dopiero w lipcu 2019 roku po wieloletnich dyskusjach przyjęto ustawę o Radzie Sądowniczej, która w sposób kompleksowy reguluje kwestie związane z funkcjonowaniem organów wymiaru sprawiedliwości. Zgodnie z przyjętą ustawą Rada Sądownicza jest niezależnym organem, który ma przede wszystkim dbać o edukację i szkolenia sędziów oraz zachowanie wysokich standardów etycznych wymiaru sprawiedliwości. W kompetencjach Rady nie znalazły się zadania związane z nominacjami sędziowskimi. Obecnie w Irlandii podmioty mające stać na straży niezawisłości i niezależności sędziów wciąż działają w systemie rozproszonym. Żaden podmiot nie jest organem konstytucyjnym, co zdecydowanie osłabia ich pozycję oraz możliwości działania. Trzeba również przyznać, że rozproszenie funkcji związanych z działalnością wymiaru sprawiedliwości sprawia, że brakuje organu, który miałby pełne kompetencje oraz był wyposażony w narzędzia, które umożliwią skuteczną ochronę niezależności sędziów.

\section{SKŁAD I ORGANIZACJA ORGANÓW}

Rada Doradcza do spraw Nominacji Sędziowskich (dalej również: Rada) zajmuje się wyłanianiem i opiniowaniem kandydatów na sędziów oraz informowaniem rządu o tym, czy osoby te mają przymioty niezbędne do sprawowania wymiaru sprawiedliwości. W skład Rady wchodzi Prezes Najwyższego Trybunału Sprawiedliwości jako jej przewodniczący, Prezes Sądu Najwyższego, Prezes Sądu

7 M.J.S. Moran, Impartiality in Judicial Appointments: An Absent Concept, 10 Trinity C.L. Rev. 5, 2007, s. 9.

8 D. Hogan, Who Is to Guard the Guardians: How Are Judges to Be Selected, 17 Hibernian L.J. 129, 2018, s. 130.

9 https://aji.ie/supports/the-interim-judicial-council/ (dostęp: 23.09.2018).

10 Ibidem. 
Apelacyjnego, prezes sądu okręgowego, prezes stanowego sądu apelacyjnego, Prokurator Generalny, przedstawiciele adwokatury oraz nie więcej niż trzy osoby wyznaczone przez Ministra Sprawiedliwości i Równouprawnienia, które cechują się odpowiednim doświadczeniem ${ }^{11}$.

Posiedzenia Rady zwoływane są przez jej przewodniczącego najpóźniej na dziesięć dni przed planowaną datą posiedzenia ${ }^{12}$. Przewodniczący Rady w uzasadnionych, pilnych przypadkach może zwołać posiedzenie z dwudniowym wyprzedzeniem. Posiedzenia Rady uznaje się za ważne, jeśli weźmie w nich udział ponad połowa jej członków. Jeśli w posiedzeniu Rady nie bierze udziału żaden z nich, posiedzeniu przewodniczy inny członek Rady obecny na jej posiedzeniu. Jak wynika z raportu przedstawionego przez Radę, w 2018 roku Rada zebrała się na sześciu posiedzeniach, opiniując na każdym z nich kandydatów na urzędy sędziowskie ${ }^{13}$. Głosowania w trakcie posiedzeń Rady są jawne i odbywają się poprzez podniesienie ręki. Wszelkie decyzje powinny być podejmowane większością głosów, w przypadku równej liczby głosów rozstrzyga głos osoby, która przewodniczy posiedzeniu. Za organizację głosowania i jego zaprotokołowania odpowiedzialny jest sekretarz.

Rada może w każdej chwili powołać co najmniej trzyosobowe podzespoły w celu wykonywania swoich obowiązków w zakresie opiniowania i przedstawiania rządowi kandydatów na sędziów. Podzespoły mogą być powołane przede wszystkim w celu promowania wniosków o nominacje sędziowskie, sporządzania formularzy wniosków o powołanie na urzędy sędziowskie, zasięgania opinii w sprawie kandydatów na urzędy sędziowskie, planowania i organizowania rozmów z kandydatami na urząd, a także do realizacji innych zadań, które Rada uzna za niezbędne w celu wypełnienia obowiązków z części IV Courts and Court Officers Act.

Zgodnie z nową regulacją Rada Sądownicza składa się z Ministra Sprawiedliwości i sędziów Sądu Najwyższego, przewodniczącego i sędziów Sądu Apelacyjnego, wyższych sądów oraz sądów okręgowych i stanowych. W praktyce oznacza to włączenie w struktury Rady wszystkich orzekających sędziów. W strukturach Rady mają funkcjonować różne komitety zajmujące się realizacją poszczególnych jej funkcji, a za prace całego organu odpowiedzialny jest jej zarząd.

Biuro do spraw obsługi sądów (dalej również: Biuro) jest zarządzane przez radę składającą się z jej przewodniczącego i siedemnastu innych członków. Przewodniczącym rady jest prezes Najwyższego Trybunału Sprawiedliwości, a pozostałymi jej członkami przedstawiciele ministerstwa sprawiedliwości, zawodów prawniczych, związków zawodowych, pracowników sądów oraz świata biznesu.

Rada Biura opracowuje wytyczne pracy Biura i sprawuje ogólny nadzór nad działalnością dyrektora zarządzającego. Jej zadaniem jest zapewnienie najbardziej

11 The Courts and Court Officers Act, 1995, nowelizowana w 2002 roku.

12 Rules of the Judicial Appointments Advisory Board.

13 Judicial Appointments Advisory Board Annual Report 2018. 
efektywnego wykorzystania zasobów Biura oraz osiąganie celów założonych przez rząd i Ministra Sprawiedliwości i Równouprawnienia w takim zakresie, w jakim mogą one wpływać na funkcjonowanie wymiaru sprawiedliwości Irlandii. Rada Biura może utworzyć komisje, które odpowiadają za poszczególne dziedziny funkcjonowania Biura. Obecnie utworzono pięć takich komisji, które odpowiedzialne są za poszczególne aspekty pracy. Jej członkowie powinni mieć specjalistyczną wiedzę, która umożliwi im pracę w komisjach.

Opisane organy charakteryzują się zmienną strukturą oraz sposobem organizacji ich pracy. Wydaje się, że brak jednolitego kierunku i sposobu działania tych organów, powoduje nie tylko nieprzejrzystość, ale przede wszystkim zmniejsza zaufanie obywateli do wymiaru sprawiedliwości. Każdy z wskazanych organów ma niezależne od siebie kompetencje.

\section{UPRAWNIENIA I KOMPETENCJE}

Rada Doradcza do spraw Nominacji Sędziowskich zajmuje się przede wszystkim opiniowaniem kandydatur osób, które zgłosiły gotowość do podjęcia się urzędu sędziowskiego. Osoba, która zamierza ubiegać się o to stanowisko, musi wypełnić formularz aplikacyjny i przekazać Radzie wszelkie informacje, jakie ta uzna za wymagane w celu wnikliwego przeanalizowania kandydatury. Rada publikuje ogłoszenia o wakatach na stanowiskach sędziowskich na wniosek Ministra Sprawiedliwości i Równouprawnienia oraz przeprowadza proces rekrutacyjny oraz przekazuje Ministrowi informacje na temat osób, które pozytywnie przeszły procedurę przed Radą. Przewodniczący Rady po otrzymaniu wniosku Ministra przekazuje informacje pozostałym członkom oraz zwołuje posiedzenie Rady. Podczas posiedzenia Rada opiniuje złożone kandydatury. Następnie sekretarz Rady zasięga opinii Rady Adwokackiej oraz Izby Radców Prawnych w sprawie zgłoszonych kandydatów. Zebrane opinie wraz z oceną dokonaną przez Radę przekazywane są Ministrowi Sprawiedliwości i Równouprawnienia.

Biuro do spraw obsługi sądów jest organem, który zajmuje się zarządzaniem sądami, świadczeniem usług wsparcia dla sędziów, przygotowywaniem i wydawaniem informacji publicznych na temat pracy sądów i sędziów, zarządzaniem i utrzymaniem budynków sądowych oraz zapewnieniem udogodnień dla użytkowników sądów. Dodatkowe uprawnienia przyznane Biuru na mocy the Courts Service Act z 1998 roku ${ }^{14}$ obejmują prawo do rozporządzania gruntami sądów, zawierania umów w imieniu sądów, składania wniosków do Ministra Sprawiedliwości i Równości w odniesieniu do spraw związanych z reformą, rozwojem i podziałem jurysdykcji między sądami i odpowiedzialne jest za wszelkie aspekty związane z funkcjonowaniem sądów (z wyjątkiem funkcji orzeczniczych).

14 The Courts Service Act 1998. 
Jak wynika z raportu Biura za 2017 rok, zajmuje się ono w ostatnich latach przede wszystkim modernizacją budynków sądów, aby zapewnić ich dostępność osobom niepełnosprawnym. Ponadto pracuje nad stworzeniem platformy elektronicznej, która umożliwi interesantom załatwienie mniejszych spraw bez konieczności udania się do sądu, na przykład umożliwiając ukaranym zapłatę mandatów drogowych przez internet bez konieczności wzięcia udziału w rozprawie, liczba rozpatrywanych w sądzie w tym zakresie spraw zmniejszyła się o $40 \% 15$. Biuro utworzyło również portal umożliwiający ubieganie się o odnowienie określonych prawem licencji online, co w sposób znaczący odciążyło sądy, prowadzi też prace w celu stworzenia bezpiecznej i przyjaznej przestrzeni w sądach dla ofiar przestępstw, tak aby nie musiały one być narażone na spotkanie z oprawcą, na przykład na korytarzu sądowym.

Radę Sądowniczą wyposażono w wiele funkcji związanych przede wszystkim z edukacją sędziów, zapewnieniem wysokich standardów ich pracy oraz reprezentowaniem sędziów w kontaktach zewnętrznych. Zostały jej również przyznane uprawnienia w zakresie badania skarg wniesionych przez podmioty prywatne związanych ze szkodami przez nie poniesionymi, wynikającymi z nieprawidłowego lub niegodnego urzędu zachowania sędziego. Może również rozpatrywać skargi wniesione w postępowaniu nieformalnym przez samych sędziów, a także wydawać rekomendacje i zalecenia skierowane albo do poszczególnych sędziów, którzy dopuścili się naruszeń, albo większego ich grona.

\section{PRAKTYKA USTROJOWA}

Ustawowe kompetencje Biura do spraw obsługi sądów, Rady Sądowniczej oraz Rady Doradczej do spraw Nominacji Sędziowskiej wydają się wyjątkowo szerokie. Jednak jak to często bywa, ramy prawne ich działań w wielu przypadkach rozmijają się z praktyką. Z uwagi na zbyt krótki okres obowiązywania ustawy o Radzie Sądowniczej (w chwili pisania artykułu raptem trzy miesiące) w niniejszej części organ ten zostanie pominięty.

Informacja na temat wakatów na stanowiskach sędziowskich jest publiczna i ogłaszana zarówno w wybranych dziennikach urzędowych, jak i na stronach internetowych organów odpowiedzialnych za wybór i promocję sędziów. Jednocześnie procedura powoływania kandydatów na urzędy sędziowskie budzi słuszne niepokoje społeczne, a także powoduje krytykę ze strony praktyków i teoretyków prawa. Rada Doradcza do spraw Nominacji Sędziowskich nie korzysta z przysługującego jej uprawnienia do przeprowadzania rozmów kwalifikacyjnych z kandy-

15 Tuarascáil Bhliantúil Annual Report 2017, http://www.courts.ie/Courts.ie/library3.nsf/ (WebFiles)/8000F0BA4F127EE7802582CD00338311/\$FILE/Courts\%20Service\%20Annual\%20 Report\%202017.pdf (dostęp: 23.09.2018). 
datami na sędziów oraz nie bierze udziału w podejmowaniu decyzji o zatrudnieniu danej osoby na urząd sędziowski ${ }^{16}$. Z uwagi na to, że kandydata na sędziego mianuje ostatecznie Prezydent zgodnie z art. 35 irlandzkiej konstytucji, stanowi to jeden z przejawów zachwiania tradycyjnego modelu trójpodziału władzy i wciąż budzi słuszny niepokój wśród praktyków i teoretyków prawa ${ }^{17}$. Rada nie udziela też wskazówek co do zatrudnienia potencjalnego kandydata ani nie korzysta ze swojego uprawnienia do zapraszania wybranych przez siebie osób do zgłoszenia swojej kandydatury. Wydaje się, że jest to niemożliwe do zrealizowania z uwagi na liczbę zgłaszanych kandydatur. Tylko w 2017 roku Rada rozpatrzyła blisko pięćset aplikacji.

Pomimo utworzenia w 1995 roku Rady Doradczej do spraw Nominacji Sędziowskich wciąż aktualna zdaje się opinia, że nominacje na wyższe stanowiska sędziowskie w Irlandii nadal dokonywane są nie na podstawie wiedzy i doświadczenia kandydatów, lecz na podstawie ich preferencji politycznych ${ }^{18}$. Należy przyznać, że większość sędziów wyższego szczebla w codziennej pracy dokłada wszelkich starań, aby swoje obowiązki wykonywać profesjonalnie i nie narazić się na oskarżenia o stronniczość polityczną, jednak sposób, w jaki głosują oni za przyjęciem poszczególnych decyzji, w rzeczywistości w znaczący sposób wpływa na ich dalszą karierę ${ }^{19}$. Jednocześnie sama procedura mianowania sędziów jest tajna i nie podlega społecznej kontroli. Mimo utworzenia Rady i przekazania w jej ręce części kompetencji decyzja o mianowaniu konkretnego sędziego pozostaje w wyłącznej dyskrecji władzy wykonawczej, która nie musi wskazywać powodów stojących za określonym wyborem ${ }^{20}$.

Wydaje się, że w Irlandii niezbędna jest reforma przepisów dotyczących wyboru i awansowania sędziów. Największym problemem jest, że Rada nie ma uprawnień do brania udziału w procedurze wyboru Prezesa Najwyższego Trybunału Sprawiedliwości, Prezesa Sądu Najwyższego oraz Prezesa Sądu Apelacyjnego, a co ważniejsze nie odgrywa żadnej roli w procesie awansowania sędziów. Wątpliwości budzi również, że jej prace w dużej części są tajne, jak też brak uprawnień do wydawania wiążącej opinii na temat poszczególnych kandydatów oraz niemożlność przeprowadzania rozmów kwalifikacyjnych.

The Judicial Council Act zmienił ramy prawne odpowiedzialności dyscyplinarnej sędziów, jednak wciąż o usunięciu z urzędu może zadecydować jedynie parlament. Kara ta jest zasądzana wyjątkowo rzadko. Nawet w sytuacjach poważnych oskarżeń o popełnienie przestępstw, jak posiadanie pornografii dziecięcej, procedura impeachementu nie zawsze zostaje uruchomiana, a w przeważającej

\footnotetext{
16 Judicial Appointments Advisory Board Annual Report 2017, s. 20.

17 M.J.S. Moran, op. cit., s. 11.

18 B. Dolan, Constitutional Law and Constitutional Rights in Ireland, Dublin 1984, s. 70.

19 M.J.S. Moran, op. cit., s. 12.

20 Ibidem, s. 13.
} 
części sędziowie z obawy o swoją opinię sami zrzekają się urzędu ${ }^{21}$. Obecnie pojawiła się możliwość wszczęcia postępowań dyscyplinarnych wobec sędziów, którzy w rażący sposób naruszyli przepisy prawa, wydając ostateczne orzeczenia w sprawach zawisłych w sądach (do czasu wejścia w życie nowej regulacji takiej możliwości nie było) ${ }^{22}$.

Należy również wziąć pod uwagę zalecenia Grupy Państw przeciwko Korupcji Rady Europy dla Irlandii z 2014 roku ${ }^{23}$. W swoim raporcie Grupa rekomenduje ustanowienie niezależnego od administracji publicznej organu, który będzie miał zapewnione odpowiednie środki techniczne i organizacyjne w celu skutecznej ochrony niezawisłości sądów. Grupa wskazuje również, że mimo poinformowania przez rząd irlandzki o trwających pracach legislacyjnych, w związku z tym, że żadne konkretne propozycje nie zostały jej przedstawione, utrzymuje zalecenie w mocy. Wydaje się, że wejście w życie nowej ustawy spowoduje, że chociaż w części zalecenia te przestaną być aktualne.

Ponadto zarekomendowano również stworzenie przejrzystych zasad dotyczących powoływania, awansowania oraz przenoszenia sędziów, tak aby zapewnić wybór najbardziej wykwalifikowanych i doświadczonych kandydatów na najwyższe stanowiska sędziowskie. System wyboru i promowania sędziów powinien zapewniać transparentność polityczną, tak aby osobisty światopogląd sędziów nie wpływał na ich mianowania (lub też niemianowania) na wyższe pozycje. Grupa Państw Przeciwko Korupcji Rady Europy wskazuje na konieczność zastąpienia obecnie funkcjonującej Rady Doradczej do spraw Nominacji Sędziowskich nowym organem, który zapewniłby większą przejrzystość dokonywanych wyborów.

Zaleceniem jest również stworzenie jasnych i demokratycznych reguł zatrudniania sędziów, a także stworzenie formalnego kodeksu etyki sędziów. Ponadto Grupa wskazuje na konieczność sformalizowania systemu kształcenia sędziów.

\section{PODSUMOWANIE}

Co do zasady sposób organizacji wymiaru sprawiedliwości w Irlandii jest pozytywnie oceniany zarówno przez jej obywateli, jak i organy Unii Europej-

${ }^{21}$ L. Cahillane, Judicial Discipline: Where Do We Stand? A Consideration of the Curtin Case, „Irish Law” 27, 2009, s. 26.

${ }^{22}$ M. Clifford, A ,Quite Improper” Ruling on the Judiciary, Irish Examiner (Dublin, 6 November 2013), http://www.irishexaminer.com/viewpoints/analysis/a-quite-improper-ruling-on-the-udiciary-248603.html (dostęp: 23.09.2018).

23 Corruption prevention in respect of members of parliament, judges and prosecutors. Compliance Report. Ireland. 20-24 marca 2017 roku, http://justice.ie/en/JELR/GRECO_Compliance_ Report_-_Corruption_Prevention_in_Respect_of_Members_of_Parliament,_Judges_and_Prosecutors.pdf/Files/GRECO_Compliance_Report_-_Corruption_Prevention_in_Respect_of_Members_of_Parliament,_Judges_and_Prosecutors.pdf (dostęp: 23.09.2018). 
skiej. Sędziowie w Irlandii cieszą się autorytetem oraz społecznym przekonaniem o słuszności podejmowanych przez nich decyzji. Jednocześnie to społeczne zaufanie ulega regularnie deprecjacji z uwagi na afery społeczno-polityczne, których bohaterami są sędziowie zarówno niższych instancji, jak i ci piastujący najwyższe stanowiska.

Pomimo zdecydowanie pozytywnej oceny wymiar sprawiedliwości zmaga się z typowymi również dla innych krajów problemami. W systemie prawnym common law, w którym sędziowie odgrywają ogromną rolę w procesie interpretacji, a w wielu przypadkach również de facto stanowienia prawa, ich niezależność jest szczególnie istotna.

Wątpliwości budzi silna pozycja władzy wykonawczej względem sądownictwa. Nieprzejrzyste procedury w zakresie powoływania i promowania sędziów, a także nieproporcjonalność kar stosowanych w postępowaniach dyscyplinarnych sprawiają, że niezależność sądów nie jest w sposób właściwy zagwarantowana. Prowadzi to do zachwiania klasycznego trójpodziału władzy, a co za tym idzie naruszenia zasady demokratycznego państwa prawnego. Kultura tajemnicy, jaka towarzyszy procedurom wyboru sędziów, powoduje spadek zaufania społecznego do podejmowanych przez nich decyzji. Co więcej, również sami sędziowie nie mają pewności, że ich osobisty światopogląd nie będzie miał wpływu na dalszy rozwój ich kariery. Może to rodzić pewną zachowawczość w podejmowanych decyzjach, a w konsekwencji orzekanie nie tylko na podstawie konstytucji i ustaw, lecz także czynników trzecich, jak poglądy polityczne przedstawicieli władzy wykonawczej czy nastroje społeczne.

Należy jednak zauważyć, że w sposób zdecydowanie pozytywny powinna zostać oceniona praca Biura do spraw obsługi sądów. Działania na rzecz uproszczenia komunikacji z sądem, dostępności budynków sądów dla osób niepełnosprawnych, a także podejmowanie odpowiednich kroków w celu odciążenia sędziów poprzez stworzenie platform online, dzięki którym obywatele mogą uznać i zapłacić mandat, a także ubiegać się o licencję, sprawiają, że wymiar sprawiedliwości zyskuje ,ludzką" twarz.

\section{A DISPERSED SYSTEM OF BODIES SAFEGUARDING THE INDEPENDENCE OF JUDGES IN IRELAND}

Summary

In the rankings conducted by the European Commission, the judicial system in Ireland was classified as the second in Europe due to the high degree of independence of the courts from other bodies. At the same time, this system, unlike in many other European countries, is strongly dispersed. Recent years have been a time of reforming the organisation of the judiciary, and the Judicial Council Act, introduced in July 2019, was supposed to solve most of the burning problems. Despite equipping the newly-established Judicial Council with a number of competences, it seems 
that without a thorough change of the whole system and creation of a body that would be responsible for performing at least most of the tasks related to the administration of the judiciary, the situation of judges in Ireland will not improve.

Keywords: Ireland, judicial reform, Judicial Council

\section{BIBLIOGRAFIA}

Cahillane L., Ireland's System for Disciplining and Removing Judges, 38 Dublin U. L.J. 55, 2015.

Cahillane L., Judicial Discipline: Where Do We Stand? A Consideration of the Curtin Case, „Irish Law" 27, 2009.

Clifford M., A „Quite Improper” Ruling on the Judiciary, lrish Examiner, Dublin 2013.

Dolan B., Constitutional Law and Constitutional Rights in Ireland, Dublin 1984.

Guarmieri C., Pederzoli P., The Power of Judges, Oxford 2002.

Hogan D., Who Is to Guard the Guardians: How Are Judges to Be Selected, 17 Hibernian L.J. 129, 2018.

Moran M.J.S., Impartiality in Judicial Appointments: An Absent Concept, 10 Trinity C.L. Rev. 5, 2007.

O'Donnell D., Some Reflections on the Independence of the Judiciary in Ireland in 21st Century Europe, 19 Trinity C.L. Rev. 5, 2016.

O’Higgins T.F., The Irish Legal System, 31 Irish Jurist (N.S.) 1. 